\title{
MENGOPTIMALKAN SUMBER DAYA ARKEOLOGI \\ SEBAGAI DAYA TARIK WISATA UNTUK KETAHANAN BUDAYA \\ (Studi Kasus Sumber Daya Arkeologi di Provinsi Papua) \\ (Optimizing Tourisme Attractions for Cultural Endurance: A Case Study of \\ Archaeological Resources in Papua)
}

\section{Ni Komang Ayu Astiti}

Asisten Deputi Penelitian Pengembangan Kebijakan Kepariwisataan Kementerian Pariwisata Jl. Medan Merdeka Barat No. 17 Jakarta 10110

Telepon (021) 3838593, Fax (021) 34830644 E-mail: nikomangayu69@gmail.com

\section{INFO ARTIKEL}

\section{Histori artikel}

Diterima: 29 Juli 2016

Direvisi: 26 Agustus 2016

Disetujui: 14 Oktober 2016

\section{Keywords:}

resources,

archeology,

Papua,

tourism,

identity

\section{Kata kunci: \\ sumber daya, arkeologi, \\ Papua, \\ pariwisata, \\ identitas}

\section{ABSTRACT}

Development of the tourism sector contributes a sizeable foreign exchange after oil and gas, coal, and oil palm. The govemment has also set a target of 20 million foreign tourists visit and 275 local tourist movement in 2019. Entering the era of globalization the movement of people from one country and region more quickly because the distance is getting closer, so it supports the growth of tourism. These conditions have a positive impact on the economy and science and technology, but social change is very vulnerable to the impact on the weakening of the resilience of culture in society. For that how to increase the resilience of culture by minimizing the negative effects of tourism development in the era of globalization in Papua is very important. Trend rating is currently more concemed about the quality of experience and a tendency to look for something unique and authentic and can not be found in the region or country. To meet market demand trends and this can be done by presenting archaeological resources in Papua as a tourist attraction. Optimizing the archaeological resources in Papua as a tourist attraction that can be empowered to improve the resilience of culture in addition to providing economic benefits is the goal of this research. The study was conducted with the literature study and survey and using descriptive analysis techniques - qualitative. From the results of analysis show that Papua has the potential archaeological resources can still be presented authenticity and contextualization. Unlock the value of cultural and archaeological resources significance in the present context to make it as a tourist attraction in Papua embryonic formation of a positive image and local identity as multi cultur values, solidarity, unity and unity, mutual assistance and proud of their own culture.

\footnotetext{
ABSTRAK

Pembangunan sektor pariwisata memberikan kontribusi devisa yang cukup besar setelah minyak dan gas, batubara, dan kelapa sawit. Pemerintah juga telah menetapkan target kunjungan 20 juta wisman dan 275 pergerakan wisatawan nusantara di tahun 2019. Memasuki era globalisai pergerakan manusia dari suatu Negara dan daerah semakin cepat karena jarak semakin dekat, sehingga sangat mendukung pertumbuhan pariwisata. Kondisi ini mempunyai dampak positif di bidang ekonomi dan IPTEK, tetapi perubahan sosial sangat rentan yang berdampak pada melemahnya ketahanan budaya di masyarakat. Untuk itu bagaimana meningkatkan ketahanan budaya dengan meminimalisasi pengaruh negatif pembangunan pariwisata pada era globalisasi di Papua sangat penting dilakukan.Trend wisatawan saat ini lebih memperhatikan kualitas pengalaman dan kecenderungan untuk mencari sesuatu yang unik dan otentik serta tidak ditemukan di daerah atau negaranya.Untuk memenuhi trend dan permintaan pasar ini dapat dilakukan dengan menyajikan sumber daya arkeologi di Papua sebagai daya tarik wisata. Mengoptimalkan sumber daya arkeologi di Papua sebagai daya tarik wisata agar dapat diberdayakan untuk meningkatkan ketahanan budaya masyarakat selain memberikan manfaat ekonomi merupakan tujuan dari penelitian ini. Penelitian dilakukan dengan studi pustaka dan survei serta menggunakan teknik analisis deskriptif-kualitatif. Dari hasil analisis diketahui bahwa Papua mempunyai potensi sumber daya arkeologi masih
} 
dapat disajikan keaslian dan kontekstualisasi. Memunculkan nilai dan makna budaya sumber daya arkeologi dalam konteks kekinian dengan menjadikannya sebagai daya tarik wisata di Papua merupakan embrio terbentuknya citra positif dan identitas lokal seperti nilai multi kultur, solidaritas, persatuan dan kesatuan, gotong royong dan bangga dengan kebudayaan sendiri.

\section{PENDAHULUAN}

Bangsa Indonesia dalam rangka mempertahankan eksistensi serta untuk mewujudkan cita-cita dan tujuan nasionalnya harus memiliki suatu ketahanan nasional yang tentunya sangat tergantung pada ketahanan sosial budaya masyarakatnya. Ada dua kekuatan yang mendorong dinamika budaya di masyarakat yaitu internal factor berupa kekuatan dari dalam masyarakat sendiri dan kekuatan dari luar (external factor) seperti perubahan lingkungan dan kontak antar budaya. Meningkatkan pemahamanmasyarakat akan nilai dan makna budaya yang dimiliki atau diwariskan oleh generasi sebelumnya menjadi faktor terpenting untuk prosespembentukan dan pemantapanidentitas dan kesadaran nasional di tengah arus globalisasi yang semakin kuat. Proses globalisasi banyak memberikan nilai positif terutamakearahkemajuanekonomidan IPTEK, tetapi juga dapat berpengaruh negatif terutama di ketahanan sosial budaya masyarakatnya. B a g a i m a n m e n in g kat kan ketahananbudaya dengan meminimalisasi pengaruh negatif arus globalisasi sangat penting dilakukan dimana setiap daerah atau bangsa mempunyai strategi yang berbedabeda tergantung pada potensi, falsafah, budaya dan dinamika budaya yang pernah dialami.

Pada era globalisasi saat ini perkembangandalam bidang informasi, telekomunikasi dan transportasi sagat pesat, sehingga jarak dan batas antar daerah atau belahan dunia semakin pendek. Revolusi ini berdampak pada lahirnya homogenisasi di masyarakat yang dapat terjadi di berbagai aspek baik pendidikan, budaya bahkan ekonomi masyarakat. Sementara itu, di sisi lain revolusi globalisasi juga melahirkan sifat heterogen atau keargaman yang ditandai dengan munculnya pribadi-pribadi yang khas dengan pola hidupnya sendiri-sendiri. Gaung globalisasi saat ini semakin cepat dan besar dirasakan masyarakat sampai pada masyarakat pedesaan atau daerah terpencil.

Kebijakan diberlakukanya MEA (Masyarakat Ekonomi ASEAN), kebijakan bebas Visa, serta kebijakan pemerintah untuk memberikan kebebasan kapal berbendera asing untuk bersandar atau berlabuh di luar lima pelabuhan embarkasi yang telah ditetapkan berdampak pada semakin pendek dan sekat antar negara. Kebijakan ini diharapkan dapat lebih meningkatkan perekonomian nasional terlebih meningkatkan devisa melalui pengembangan pariwisata yang sangat di dukung oleh potensi budaya lokal sebagai daya tarik wisata. Kebijakan ini tentunya juga harus memperhatikan dampak terhadap sosial budaya di masyarakat yang dapat mengancam ketahanan nasional dan budaya lokal.

$\begin{array}{lll}\text { Masyarakat di } & \text { dalam suatu } \\ \text { bangsa terjadi } & \text { proses-proses } \\ \text { pembentukan dan perkembangan }\end{array}$ budaya yang berfungsi sebagai penanda jati diri dari bangsa tersebut. Budaya selalu mengalami dinamika yang berakibat pada jati diri budaya pada masing-masing ditandai oleh kekhasan yang menyangkut pada semua komponen unsur kebudayaan 
baik terkait dengan fungsi sosial maupun fungsi teknisnya (Sedyawati, 2006: 328-329).

\section{Pada masa globalisasi} kebudayaan seseorang atau suatu bangsa cenderung dan secara cepat berpengaruh dan mempengaruhi kebudayaan negara lain bahkan peradaban dunia. Arus yang cepat ini menyebabkan setiap negara akan mengalami pengambialihan beberapa elemen budaya asing tertentu atau sebaliknya. Dalam proses ini setiap bangsa akan berusaha menyesuaikan budaya mereka dengan perkembangan budaya baru yang dengan arus pesat datang dari negara luar agar mereka dapat melanjutkan kehidupan dan menghindari kehancuran atau bahkan hilangnya budaya asli dan tercabut dari akarnya. Untuk menghindari ini setiap negara harus memperkuat ketahanan budaya dengan memperkokoh dimensi budaya dan melestarikan struktur nilainilai dan makna budaya yang dimiliki agar terhindar atau meminimalisasi pengaruh buruk dari dampak globalisasi.

Indonesia dengan letak geografis yang mempunyai banyak daerah atau pulau berbatasan dengan beberapa negara asing atau dengan istilah perbatasan lintas batas (PLB) sangat lebih mudah untuk masuk dan mempengaruhi budaya masyarakat baik secara teknis maupun fungsional. Dengan kondisi ini Indonesia harus terus berupaya untuk memperkuat peran kebudayaan untuk identitas dan membangunjatidiriuntukmeningkatkan ketahanan budaya di masyarakat. Meningkatkan pemahaman dan penyadaran masalah identitas budaya sangat penting di masyarakat dalam arus globalisasi, karena identitas budaya sebuah bangsa akan dengan mudah hilang dan digantikan dengan identitas campuran yang plural.

Konsep globalisasi memunculkan berbagai interpretasi terhadap semua produk global di masyarakat sesuai dengan tingkat pemahaman dan pendidikan masyarakat. Pengikisan budaya lokal banyak dipengaruhi oleh desakan global yang semakin kuat sehingga nilai dan makna budaya yang plural sering diasumsikan sebagai tata nilai sosial asli (tradisional) terutama oleh generasi muda. Sementara itu, di satu sisi budaya di masyarakat juga harus berkembang sesuai dengan perkembangan budaya dunia, sehingga arus globalisasi juga sangat penting untuk kemajuan budaya nasional. Kebudayaan tanpa tradisi dan integrasimenjadi tanpa identitas, sedangkan tanpa reformasi atau tanpadisintegrasi kebudayaan akan kehilangan kemungkinan untuk berkembang, untuk memperbaharui diri, atau untuk menyesuaikan diri dengan paksaan perubahan sosial (social change coercion) (Ariani, 2011: 29-30).

Dengan alasan tersebut kurang
kuatnya ketahanan dan identitas
budaya di masyarakat sangat besar peluang adanya pergeseran nilai dan makna budaya yang yang sudah diwarisi secara turun temurun. Permasalahan ini sangat penting dan perlu adanya penanganan serius dengan memperkuat ketahanan dan identitas budaya di masyarakat.

Indonesia adalah negara yang sangat majemuk karena terdiri dari lebih dari 17.508 dengan 1.128 suku bangsa yang masing-masing mempunyai kearifan lokal dalam arti kebudayaan tradisional. Kearifan lokal di sini berbagai pola tindakan dan hasil budaya materiil yang terjabar dalam seluruh warisan budaya baik 
yang tangible maupun intangible. Seluruh hasil budaya suatu bangsa adalah sosok dari jati diri pemiliknya. Warisan budaya ini dapat dijadikan sebagai sumber daya dalam hal ini mengacu pada suatu penggunaan atau pemanfaatan tertentu dari sesuatu untuk pencapaian tujuan yang dapat diukur dari segi produktivitas (Sedyawati, 2006: 169, 382).

Tinggalan arkeologi merupakan jejak budaya penciptaan masyarakat masa lalu dalam bentuk kebudayaan materi atau warisan budaya tangible yang dapat diberdayakan untuk pemanfaatan ekonomi sebagai daya tarik wisata dan pemanfaatan ideologi untuk penguatan identitas dan jatidiri. Tinggalan arkeologi yang dapat diberdayakan untuk kepentingan ini di sebut sebagai sumber daya arkeologi.

Indonesia sangat kaya akan sumber daya arkeologi dan tersebar hampir di Sabang sampai Merauke dan berasal dari masa prasejarah sampai masa kemerdekaan. Sumber daya arkeologi yang ditemukan di masing-masing daerah mempunyai ciri khas tersendiri yang berbeda dan tidak ditemukan di daerah-daerah lainnya. Sumber daya ini dapat dikelola untuk membentengi masyarakat terhadap efek globalisasi dengan meningkatkan pemahaman mereka terhadap nilai dan makna yang terkandung sehingga ketahanan budaya masyarakat meningkat. Sumberdaya arkeologi harus diinterpretasi berdasarkan konteks sosial masyarakat dan politik dewasa ini, karena dapat memberikan manfaat yang besar bagi masyarakat luas. Terdapat tiga kepentingan pokok dalam pengelolaan tinggalan arkeologi, yaitu akademik terkait dengan pengembangan ilmu pegetahuan, ideologi berkaitan dengan jati diri dan identitas, dan kepentingan ekonomi yang berkaitan dengan pariwisata (Cleere, 1989: 9-10).

Dalam Era Global seperti saat ini, sumberdaya arkeologi dapat berperan penting dalam meningkatkan ketahanan budaya dengan penciptaan jati diri masyarakat. Di banyak negara maju dan berkembang, banyak sumber daya arkeologi dalam bentuk bangunan-bangunan atau monumenmonumen kuno dilestarikan dan dibingkai dengan lanskap dan budaya masyarakat sebagai bagian dari identitas atau jatidiri bangsa dan penduduknya. Tujuan dari kajian ini adalah untuk mengoptimalkan sumber daya arkeologi yang ada di Indonesia sebagai atraksi wisata sehingga dapat meningkatkan ketahanan budaya masyarakat di era globalisasi sekaligus memberikan manfaat secara ekonomi.

Perkembangan industri pariwisata yang menjadi sektor prioritas dalam pembangunan nasional tentunya juga meningkatkan interaksi dan mobilitas masyarakat lokal dan dunia. Persentuhan dan percampuran budaya, antar etnik dan antarbangsa tidak dapat dihindari karena wisatawan datang ke suatu destinasi tentunya dengan budayayang notabene berbeda dengan budaya lokal sehingga dapat menjadi pemicu adanya kerawanan konflik.

Untuk itu, penekanan dalam perspektif kebijakan pengembangan pariwisata juga harus bertujuan pada pembentukan ketahanan budaya, pemantapan integrasi sosial dan pemberdayaan masyarakat lokal. Perhatian terhadap aspek sosial budaya dalam pariwisata masih sangat rendah. Dengan alasan ini ini maka mengoptimalkan sumber daya arkeologi sebagai daya tarik wisata untuk meningkatkan ketahan budaya sangat mendesak untuk dilakukan. 
Kajian ini mengambil kasus sumberdayaarkeologiyangadadiPapua dengan tujuan untuk meminimalsisasi dampak perkembangan industri pariwisata sebagai pertumbuhan ekonomi dan pembangunan daerah terhadap degradasi ketahanan budaya masyarakat. Sumber daya arkeologi yang dimiliki bangsa Indonesia sangat beragam (multi cultural)dan menjadi modal yang besar pengembangan kepariwisataan sebagai daya tarik sehingga dapat memberikan pengalaman yang berbeda kepada wisatawan.

Hal ini senada dengan apa yang dikemukakan oleh Boniface (1995) bahwa tanpa dibedakan kebudayaan semua derah tujuan wisata di dunia akan tampak serupa;tanpa warisan budaya yang berbedabeda, tempat-tempat di dunia tidak banyak dapat ditawarkan kepada wisatawan. Pengembangan pariwisata di Indonesia bertujuan untuk: a). meningkatkan pertumbuhan ekonomi, b). meningkatkan kesejahtraan rakyat, c). menghapus kemiskinan, d). mengatasi pengangguran, e). melestarikan alam,lingkungan, dan sumberdaya, f). memajukan kebudayaan, g). mengangkat citra bangsa, h). memupuk rasa cinta tanah air, i). memperkukuh jati diri dan kesatuan bangsa, dan j). mempererat persahabatan antar bangsa.

Daya tarik wisata adalah segala sesuatu yang memiliki keunikan, keindahan dan nilai yang berupa keanekaragaman kekayaan alam, budaya dan hasil buatan manusia yang menjadi sasaran atau kunjungan wisatawan (Undang Undang No. 10 Tahun 2009). Sumber daya arkeologi adalah sumber daya dari penciptaan masyarakat masa lampau, sehingga dalam mengoptimalkan sumber daya arkeologi sebagai daya tarik wisata di Papua untuk meningkatkan ketahan budaya peninggalan kebudayaan masyarakat Papua dari masa lampau yang memiliki keunikan, keindahan dan nilai yang dapat menjadi sasaran atau kunjungan wisatawan.

Pariwisata global saat ini lebih memberikan penekanan pada pemanfaatan sumber daya budaya dan alam untuk menjadi pilihan sebagai daya tarik, sehingga sangat tepat jika sumber daya arkeologi dapat dioptimalkan sebagai sarana untuk meningkatkan ketahanan budaya di masyarakat. Papua tidak saja kaya dengan flora dan fauna, tetapi juga sumber daya arkeologi sebagai wujud budaya masyarakat masa lalu di daerah ini. Temuan beberapa peninggalan megalitikum yang berusia 40000-30000 tahun sebelum masehi sampai pada situs termuda berupa peninggalan masa kolonial sangat potensial dikembangkan sebagai daya tarik wisata.

Berkembangnya pariwisata ini secara tidak langsung akan meningkatkan kesadaran, pemahaman dan rasa cinta tanah air masyarakat sehingga ketahanan budaya masyarakat akan meningkat. Peningkatan ketahanan budaya masyarakat sangat penting untuk membentengi diri terhadap semakin derasnya arus globalisasi. Berkunjung ke destinasi yang memanfaatkan sumber daya arkeologi sebagai atraksi wisata, dapat memberikan rasa bangga dan cinta terhadap kebudayaan dan bangsanya serta menimbulkan rasa persaudaraan dan saling menghormati perbedaan budaya dari masing-masing daerah serta timbul rasa persatuan.

Situs-situs arkeologi yang tersebar di seluruh Nusantara termasuk yang ada di Papua mempunyai potensi 
besar untuk diberdayakan untuk tujuan ekonomi dan ideologi terkait identitas budaya dan jati diri. Untuk tujuan meningkatkan ketahanan budaya masyarakat sangat penting menjadi perhatiaan pada era globalisasi. Mengoptimalkan sumber daya arkeologi sebagai daya tarik wisata untuk meningkatkan ketahanan budaya merupakan strategi yang efektif, karena trend pariwisata yang berkembang saat ini. Metode yang digunakan untuk menjawab permasalahan yang ada adalah:

1. Pengumpulan Data

a. Studi pustaka (hard data), mengumpulkan data sekunder dari hasil-hasil penelitian terdahulu, serta artikel-artikel yang mendukung untukmenjawab permasalahan dalam tulisan ini.

b. Observasi langsung (soft data) di lakukan pada situs-situs arkeologi yang mempunyai daya tarik wisata baik domestic maupun mancanegara.

c. Melakukan wawancara dengan beberapa stakeholder terkait pengembangan sumber daya arkeologi sebagai daya tarik wisata sekaligus peningkatan ketahanan budaya.

1. Pengumpulan data dilakukan pada 10 - 18 September 2015, observasi di lakukan di Kabupaten Raja Ampat.

2. Analisis Data dan Interpretasi Data Analisis dilakukan dengan pendekatan deskriptif-kualitatif dengan melakukan deskripsi potensi, kelemahan, peluang dan tantangan dalam mengoptimalkan sumber daya arkeologi sebagai daya tarik wisata untuk meningkatkan ketahanan budaya.

PEMBAHASAN
Potensi Sumber Daya Arkeologi di Papua

Potensi adalah kemampuan yang mempunyai kemungkinan untuk dikembangkan, kesanggupan, kekuatan, dan daya (Kamus Besar Bahasa Indonesia, 2007: 890). Sementara itu potensi wisata adalah berbagai sumber daya yang terdapat di sebuah daerah tertentu yang bisa dikembangkan menjadi atraksi wisata (Pendit, 2002:21).

Sementara itu, sumber daya arkeologi di sini merupakan tinggalantinggalan arkeologi baik berupa situs, kawasan situs maupun artefak yang dapat diberdayakan masyarakat Papua sebagai daya tarik wisata untuk memperkuat ketahanan budaya. Sumber daya arkeologi sebagai potensi merupakan tinggalan-tinggalan arkeologi yang dapat sebagai sumber daya baik untuk pengembangan pariwisata maupun ketahanan budaya di masyarakat. Sumber daya arkeologi sebagai potensi wisata di Papua adalah sumber daya arkeologi yang dapat diberdayakan oleh daerah ini untuk dikembangkan menjadi suatuatraksi wisata (tourist attraction) yang sangat beragam dan berasal dari berbagai peradaban budaya.

Di Papua ditemukan situs purbakala tertua tinggalan dari masa pra-sejarah yaitu pada $30.000-40.000$ SM. Situs yang berlokasi di Kabupaten Biak ini berupa gua-gua yang pada dindingnya dijumpai lukisan-lukisan dan fosil-fosil moluska atau cangkang kerang sebagai bukti adanya kehidupan manusia pada masa lampau. Situssitus gua lainnya yaitu Situs Gua Tei di Kampung Skow Yambe, Distrik Muara Tami, Kota Jayapura dimana ditemukan fragmen gerabah polos dan gerabah dengan motif hias, situs Gua Padwa, Gua Kufrai, dan situs Gua 
Yembuken yang terletak di Biak. Situs prasejarah juga ditemukan di beberapa kampung pesisir Kawasan Danau Sentani dengan temuan sejumlah fragmen gerabah hias, gerabah polos, manik-manik, moluska, arang, tulang binatang, tulang manusia, calon alat batu yang merupakan jejak-jejak peradaban masyarakat masa lampau di kawasan ini.

Temuan prasejarah lainnya berupa perkampungan seluas 1.000 $x \mathbf{5 0 0}$ meter di Bukit Srobu, Kelurahan Abe Pantai, Kota Jayapura dengan temuan dari masa neolitikum (batu muda) dan megalitikum (batu besar) serta fragmen-fragmen gerabah dan alat serpih batu yang diperkirakan dari masa 10000 tahun sebelum Masehi. Di kawasan ini juga ditemukan tinggalan budaya dari masa megalitikum (masa 3600 tahun sebelum Masehi) berupa meja batu, turap yang merupakan dasar sebuah permukiman, dan menhir. Dari hasil penelitian benda-benda ini dapat dianalisis bahwa kemungkinan masuknya budaya neolitik dan Megalitik ke Papua dibawa oleh masyarakat ras Austronesia dari Taiwan pada 5000 tahun sebelum masehi, dimana ada pertukaran antara suku bangsa Melanesia dan Austronesia melalui penggunaan sistem barter. Temuan lainnya adalah arca berbentuk manusia di Boven Digoel, kapak batu di Yahukimo dan alat serpih batu di Maybrat (http://sains.kompas.com/ read/2014/05/21/2123550/Kampung. Prasejarah.Ditemukan.di.Papua).

Papua juga merupakan wilayah Indonesia yang mengalami pertempuran langsung antara tentara Jepang melawan tentara Sekutu pada Perang Dunia II atau lebih dikenal sebagai Perang Pasifik (1900 - 1940). Hal ini menyebabkan di Papua banyak ditemukan tinggalan budaya dari masa kolonial seperti situs-situs di darat berupa bekas pertempuran, gua-gua perlindungan, maupun markas militer, serta peralatan tempur yang terkubur dalam tanah maupun dalam air laut. Situs Ifar Gunung, Situs Asei Pulau dan Situs Hirekombe di Kabupaten Jayapura juga merupakan jejak-jejak budaya dari masa kolonial. Bangkai pesawat tempur juga ditemukan di perairan Biak Numfor dan Sarmi, Provinsi Papua, serta Sorong dan Raja Ampat, Provinsi Papua Barat. Situs-situs Perang Pasifik lainnya juga ditemukan di Jayapura, Pulau Wakde dan Pulau Liki, Kabupaten Sarmi, Pulau Owi di Kabupaten Biak Numfor, Sausapor, Pulau Dom, dan Pulau Jefman.

Situs gua lainnya yaitu di Plato Ayamaru, Gua Kria dan Gua Toe yang terpisah sejauh $12 \mathrm{~km}$. Gua Kria mempunyai sedimen setebal dua meter dengan stratigrafi yang tak terganggu deformasi, berdasarkan jenis dan kuantitas temuan artefak sedimen ini di bagi menjadi lima satuan hunian (occupation unit). Setiap satuan sedimen mengandung artefak-artefak berupa perkakas terbuat dari tulang dan batu, sisa-sisa hewan (terutama walabi hutan, di samping cangkang-cangkang moluska). Umur lapisan-lapisan dari terbawah sampai teratas adalah sekitar 8000-1840 tahun yang lalu. Di lapisan teratas sedikit ditemukan artefak dan sisa hewan, tetapi ditemukan bekasbekas manusia yang dikubur.Tidak ada tanda-tanda bahwa pendudukAyamaru masih menggunakan gua tersebut sebagai kuburan (http://sains.kompas. com/read/2010/04/07/06421085/ Papua.Miliki.Keragaman.Arkeologi).

Situs pemukiman lainnya adalah Situs Mosandurei di mana dalam situs tersebut ditemukan alat batu, manikmanik, keramik China Dinasti Ming 
(abad XVI-XVII) dan Dinasti Ching (abad XVII-XVIII), keramik Eropa, botol Eropa dan gerabah. Keramik Eropa yang ditemukan terdapat cap pabrik pembuatnya yaitu Fregout \& Co Saastrusht Dragon Made in Holland dan Petrus Regout \& Co Maastricht made in Holland. Di situs itu juga ditemukan sisa makanan berupa cangkang moluska laut dalam jumlah banyak dan tulang binatang. Situs dipilih sebagai pemukiman masa lalu karena letak yang strategis yaitu dekat dengan sumber air tawar, dekat dengan hutan sagu dan pesisir pantai. Letak situs di atas bukit, sangat aman dan terlindungi dari serangan bajak laut yang banyak beroperasi di Teluk Cenderawasih pada abad ke-16 hingga abad ke-18 dan merupakan bagian dari jaringan niaga dengan Kesultanan Tidore (http://sains.kompas.com/ $\mathrm{read} / 2014 / 05 / 21 / 2123550 /$ Kampung. Prasejarah.Ditemukan.di.Papua).

Situs lainnya yang ditemukan di daerah ini berkaitan dengan sejarah masuknya agama Islam ke Papua, yaitu ke daerah Fakfak Papua Barat yang tidak terpisahkan dari jalur perdagangan yang terbentang antara pusat pelayaran internasional di Malaka, Jawa dan Maluku. Secara geografis Papua memiliki kedekatan relasi etnik dan kebudayaan dengan Maluku terutama Fakfak dengan Maluku Tengah, Tenggara dan Selatan, sedangkan dengan RajaAmpatmemiliki kedekatan dengan Maluku Utara. Perkembangan agama Islam di daerah Fakfak dikembangkan oleh pedagangpedagang suku Bugis melalui Banda yang diteruskan ke Fakfak melalui Seram Timur oleh seorang pedagang dari Arab bernama Haweten Attamimi yang telah lama menetap di Ambon. Proses islamisasi di wilayah Fakpak melalui jalur perdagangan, perkawinan, pendidikan non formal, dan politik
(Onim, 2006;102-105).

Jejak-jejak budaya yang ditemukan di daerah ini masjid-masjid kuno peninggalan kerajaan Islam yang pernah berkuasa gong, bedug masjid, rebana yang digunakan pada saat upacara maulid, songkok raja, tongkat cis, tanda raja dan adanya silsilah kerajaan dari kerajaan Ati-ati. Masjid-masjid kuno yang ditemukan tersebut tersebar di beberapa tempat diantaranya masjid Patimburak, masjid Werpigan dan masjid Merapi. Masjid Tua Patimburak sampai saat ini masih terpelihara dan catatan sejarah, masjid ini telah berdiri lebih dari 200 tahun yang lalu, bahkan merupakan masjid tertua di Kabupaten Fakfak. Bangunan yang masih berdiri kokoh dan berfungsi hingga saat ini dibangun pada tahun 1870 , seorang imam bernama Abuhari Kilian. Di daerah Sorong, perkembangan Islam di mulai sejak abad ke-15 ketika Raja-raja Ternate dan Tidore mengadakan pelayaran ke timur untuk mencari burung kuning yang berlokasi di Salawati. Artefak kuno dan kompleks pemakaman yang diduga menjadi pusara saudagar Arab ditemukan Balai Arkeologi Jayapura di Misool, Kabupaten Raja Ampat. Artefak dan kompleks pemakaman itu diduga berasal dari abad 17. Artinya, keduanya sudah berumur ratusan tahun (http://prokimal-online.blogspot. com/2013/01/situs-situs-arkeologimiliter-perang.html).

Potensi sumber daya arkeologi yang ditemukan di Papua sebagian besar berasal dari masa prasejarah dalam bentuk gua-gua sisa pemukiman masyarakat masa lalu dengan berbagai jejak-jejak budayanya. Potensi ini dapat dikembangkan dan dipadukan dengan keindahan alam Papua menjadi destinasi wisata minat khusus. Begitu juga dengan situs pemukiman 
Kampung Tua Mosandurei yang terletak di atas bukit tentunya sangat potensial dikembangkan sebagai destinasi wisata budaya khususnya wisata perdesaan yang mencirikan budaya lokal masyarakat Papua. Situssitus masa prasejarah ini, sebagian besar ditemukan di daerah dataran tinggi sehingga wisata budaya dapat dipadukan dengan wisata alam.

Jejak pertempuran antara tentara Jepang melawan tentara Sekutu pada Perang Dunia II sangat banyak ditemukan di kawasan ini karena berlangsung sangat lama (1900 - 1940). Jejak tinggalan perang berupa bekas pertempuran, gua-gua perlindungan, maupun markas militer dapat ditata dan dikelola sebagai salah satu destinasi yang menarik karena merupakan bukti otentik berapa besar peranan daerah ini dalam pertempuran tersebut. Begitu juga dengan beberapa peralatantempuryang masih ditemukan di kawasan ini dapat dijadikan sebagai koleksi museum dan nantinya sebagai salah satu destinasi wisata. Bangkai pesawat tempur yang ditemukan di beberapa tempat, dapat di konservasi dan menjadi atraksi wisata serta kebanggan daerah dimana bangkai pesawat ini ditemukan.

Jejak-jejak budaya militer pada masa perang dunia ini, tentunya akan menjadi daya tarik wisata tidak saja secara domestik tetapi juga masyarakat Jepang atau negaranegara Sekutu yang pada saat itu ikut dalam peperangan ini. Keinginan untuk bernostalgia atau mengenang perjuangan anggota keluarga atau warganya serta mencari jejak-jejak peradaban mereka menjadi salah satu motivasi pendorong mereka berkunjung ke Papua.

Begitu juga dengan potensi
tinggalan masa Islam dapat dikembangkan sebagai wisata sejarah (religi) untuk menarik wisatawan dari Arab Saudi untuk melakukan napak tilas melalui jalur perdagangan yang pernah dilakukan oleh nenek moyangnnya pada masa lalu. Atau mereka juga dapat melakukan ziarah ke masjid-masjid kuno dan makammakam kuno yang dipercaya sebagai makam-makam para saudagar dari negaranya. Keotentikan dan keunikan sumber daya arkeologi yang di Papua menjadi potensi besar untuk menarik kunjungan wisatawan ke daerah ini baik dengan tujuan bernostalgia maupun wisata religi dapat dijadikan sebagai bagian dari paket dengan wisata alam (http://news.metrotvnews.com/ $\mathrm{read} / 2015 / 02 / 04 / 353639 / a r t e f a k-d a n-$ makam-saudagar-arab-ditemukan-diraja-ampat).

\section{Sumber Daya Arkeologi Sebagai Daya Tarik Wisata}

Daya tarik wisata adalah segala sesuatu yang memiliki keunikan, keindahan dan nilai yang berupa keanekaragaman kekayaan alam, budaya dan hasil buatan manusia yang menjadi sasaran atau kunjungan wisatawan (UU RI No. 10 Tahun 2009). Daya tarik atau atraksi wisata menurut Yoeti (2002:5) adalah segala sesuatu yang dapat menarik wisatawan untuk berkunjung pada suatu daerah tujuan wisata, sepertinaturalattraction, cultural attraction, social attractions, dan built attraction. Jadi sumber daya arkeologi di Papua yang dapat dikembangkan sebagai daya tarik wisata adalah jejak budaya hasil ciptaan manusia masa (masa prasejarah sampai masa Perang Pasifik) yang memiliki keunikan, keindahan dan nilai yang dapat menjadi sasaran atau kunjungan wisatawan. Papua mempunyai potensi ini sangat besar sehingga perlu pengelolaan agar 
wisatawan menjadikannya sebagai faktor penarik untuk berkunjung ke daerah ini.

\begin{tabular}{lrr}
\multicolumn{3}{c}{ Pada dasarnya pengembangan } \\
pariwisata dilakukan & untuk \\
memaksimalkan & keuntungan & dan \\
meminimalkan permasalahan & (Mill,
\end{tabular}
2000: 168). Pengembangan adalah suatu proses atau cara menjadikan sesuatu menjadi maju, baik, sempurna, dan berguna. Pengembangan dalam kajian ini merupakan proses atau usaha untuk memunculkan nilai dan makna budaya yang terdapat pada setiap tinggalan arkeologi agar dapat memaksimalkan manfaatnya untuk kepentingan ekonomi melalui kepariwisataan dan kepentingan ideologi untuk peningkatan ketahanan budaya di masyarakat.

\section{Pada abad ke-20}

kecenderungan wisatawan berkunjung ke suatu destinasi dengan tujuan untuk mendapat pengalaman unik sambil ikut melestarikan sumberdaya wisata yang mereka kunjungi beserta lingkungannya. Wisatawan ini lebih memperhatikan kualitias pengalaman yang diperoleh, kualitas lingkungan, dan kualitas sosial budaya masyarakat setempat. Wisatawan ini juga mempunyai kecenderungan untuk mencari sesuatu yang unik dan otentik serta tidak ditemukan di negaranya.

Hasil studi yang dilakukan oleh Travel Industry Association and Smithsonian Magazine pada tahun 2003 menunjukkan bahwa wisatawan yang mengunjungi situs sejarah dan atraksi budaya umumnya berpendidikan lebih tinggi, dengan pendapatan lebih banyak, tinggal lebih lama dan membelanjakan uangnya lebih banyak dibandingkan dengan jenis wisatawan lainnya (Tien, 2003: 2).
Papua mempunyai warisan budaya bendawi (tangible) seperti tinggalan-tinggalan kuno dari masa prasejarah sampai masa perang Pasifik yang sangat unik serta situs-situs perkampungan kuno dengan tradisi (intangible) berupa adat istiadat dan kegiatan-kegiatan budaya. Potensi ini menjadi salah satu daya tarik wisatawan karena kekhasannya jika dibandingkan dengan daerah-daerah lain tentunya juga sangat terkait dengan bagaimana sumberdaya budaya itu dikembangkan dan disajikan. Untuk memenuhi trend dan permintaan pasar tersebut maka dalam penyajian sumber dayaarkeologi di Papua, keaslian (authenticity) dan kontekstualisasi (contextualization) sangat penting untuk dipertahankan. Sumber daya arkeologi dikembangkan sebagai daya tarik wisata tentunya tetap berpegang pada prinsip memaksimalkan keuntungan dan meminimalkan permasalahan.

Sumber daya arkeologi di Papua mempunyai sifat yang sama yaitu sangat rapuh dan jumlah yang sangat terbatas sehingga sangat perlu untuk meminimalkan kerusakannya dengan pelestarian. Pelestarian pasti bertujuan untuk sedapat mungkin mempertahankan keaslian terutama terkait nilai dan makna budaya yang terkandung. Pelestarian pada hakekatnya adalah upaya mempertahankan agar suatu sumberdaya arkeologi dapat memberikan manfaat pada masa rakat sekarang dan yang akan datang, sehingga dapat diberikan makna baru sehingga dapat kembali mempunyai makna atau arti penting bagi sistem budaya yang masih berlangsung.

Sumber daya arkeologi yang dimiliki masyarakat Papua sangat multi cultural sehingga modal besar dalam pengembangan industri pariwisata. 
Mengoptimalkannya sebagai daya tarik wisata tentunya dapat memberikan pengalaman yang berbeda dengan wisatawan, karena memiliki keunikan tersendiri. Keunikan dan perbedaan ini menjadi sumber daya yang dapat ditawarkan ke wisatawan untuk meningkatkan kualitas pengalaman wisatawan karena keingintahuan mereka bertambah.

Pariwisata adalah sisi yang tidak terpisahkan dari kehidupan manusia terlebih menyangkut aktivitas sosial serta ekonomi. Hal ini juga sudah di akui oleh berbagai oganisasi internasional diantaranya PBB, Bank Dunia serta World Tourism Organization. Dari berbagai Negara maju dan berkembang Indonesia menjadi salah satu tujuan pariwisata dunia, dan terus mengalami peningkatan dari tahun ke tahun. Pada saat ini, masa pemerintahan Kabinet Kerja, pariwisata dijadikan sebagai salah satu pertumbuhan ekonomi dan memberikan kontribusi devisa yang cukup besar setelah minyak dan gas (30 miliar dolar AS), batu bara, dan kelapa sawit.

Meningkatnya permintaan pariwisata di Indonesia berdampak pada tuntutan dalam penyediaan produk pariwisata yang berkualitas dan beragam. Setiap daerah termasuk Papua dituntut dan berupaya untuk menggali sumber daya yang dimiliki untuk kepentingan ini. Papua mempunyai sumber daya arkeologi yang dapat dikembangkan sebagai daya tarik wisata budaya yang cukup praktis dan termasuk investasi yang relatif berbiaya rendah serta permintaan wisata warisan budaya juga cukup besar dalam konteks globalisasi.

Meningkat dan berkembangnya pariwisata di Indonesia khususnya di Papua secara langsung berkaitan dengan perkembangan ekonomi di suatu daerah ( $P A D$ ) dan negara (devisa) tetapi juga harus meminimalisasi kelemahan yang diakibatkanya. Hal ini secara khusus dinyatakan oleh Haryono (2003:9) yang mengingatkan bahwa perkembangan pariwisata yang secara langsung berkaitan dengan perkembangan ekonomi sebagai salah satu sumber devisa negara, tidak akan ada artinya jika keselamatan warisan budaya tersebut tidak terjaga. Hubungan resiprokal antara pelestarian dan pemanfaatan, khususnya di sektor pariwisata merupakan dua kepentingan yang strategis. Kerangka pemikiran untuk mendekati persoalan resiprokal adalah konsep peddle or perish (Macleod, 1977:63-72) yang menyatakan bahwa benda cagar budaya dapat terancam kelestariannya apabila tidak dimanfaatkan (Riyanto, 2006:26).

Dengan mengembangkan sumber daya arkeologi di Papua sebagai daya tarik wisata tentunya dapat mengoptimalkan manfaatnya terutama secara ekonomi karena memberikan keuntungan pada masyarakat lokal. Secara sosial budaya hal ini juga memberikan manfaat untuk menumbuhkan dan meningkatkan jati diri masyarakat dan daerah untuk ketahanan budaya. Pengoptimalan manfaat ini tentunya juga meminimalisasi kerusakan dan degradasi sumber daya karena secara tidak langsung akan melestarikan sumber daya arkeologi tersebut.

Keberagaman, kekhasan dan keunikan sumber daya arkeologi sumber daya arkeologi yang tersebar di wilayah Papua dapat menjadi kebanggaan daerah dan bangsa dengan menjadikannya sebagai daya tarikwisata. Sumberdaya ini merupakan hasil cipta budaya masyarakat Papua pada masa lalu sehingga sangat kental 
dengan budaya lokal masyarakat di daerah ini. Memberdayakan sumber daya ini sebagai daya tarik wisata secara tidak langsung akan menyebarluaskan informasi nuilai dan makna budaya yang terdapat pada setiap sumber daya ini sehingga lebih mudah dipahami oleh masyarakat luas.

Semakin banyak kunjungan wisatawan ke situs-situs arkeologi terus di Papua, tentunya lebih meningkatkan kebangaan masyarakat Papua dan daerah. Meningkatnya trend wisata ini juga lebih meningkatkan rasa cinta tanah air dan budaya daerah. Masyarakat juga dapat lebih harus memahami nilai dan makna budaya serta menjadikan keanekaragaman budaya masyarakat Papua sebagai sumber kekuatan untuk ketahanan budaya bangsa.

\section{Meningkatkan Ketahanan Budaya Melalui Pariwisata di Papua}

Ketahanan budaya diartikan sebagai kondisi dinamik budaya bangsa yang berisi keuletan untuk mengembangkan kekuatan nasional dalam menghadapi ancaman dan gangguan baik dari luar maupun dari dalam, secara langsung maupun tidak langsung. Wujud ketahanan budaya tercermin dalam kondisi sosial budaya manusia yang dijiwai kepribadian nasional berdasarkan Pancasila, yang mengandung kemampuan untuk mengembangkan kehidupan sosial budaya Indonesia. Ketahanan budaya banyak dipengaruhi oleh nilai-nilai yang ditanamkan dan diyakini masyarakat maupun sistem sosial budaya dan tingkat pendidikan dalam hal ini pemahaman mereka akan nilai budaya agar mempunyai daya tahan dan kemampuan bertumpu pada kekuatan dan keunggulan budaya sendiri dalam menghadapi perubahan sosial budaya di era globalisasi.

Sumber daya arkeologi sebagai wujud kebudayaan materi dapat berfungsi untuk memberi identitas kepada masyarakat Papua karena merupakan hasil cipta masyarakat papua pada masa lalu dan mempunyai ciri khas etnik masyarakat Papua. Sumber daya ini juga mempunyai nilai dan makna budaya yang tinggi yaitu nilai informasi, estetika, simbolik dan ekonomi sehingga menjadi kebanggaan masyarakat dan menjadikan sebagai identitas masyarakat dan daerahnya. Sumber daya arkeologi sebagai daya tarik wisata juga dapat berfungsi sebagai sarana untuk saling berkomunikasi (diplomasi budaya) sehingga dapat memperkuat rasa solidaritas masyarakat. Untuk mencapai tujuan ini, maka hasil karya masyarakat Papua juga harus dipahami oleh masyarakat luas termasuk wisatawan dengan memberikan informasi yang benar tentang nilai dan makna budaya pada konteks kekinian. Dengan menjadikan sumber daya arkeologi sebagai daya tarik wisata, maka akan mempermudah akses masyarakat luas dan informasi yang terkandung juga lebih mudah dipahami oleh masyarakat seperti nilai multikultur, saling menghormati dan nilai gotong royong.

Di beberapa negara maju perbedaan warisan budaya dan etnik dengan berbagai tinggalan budaya materinya dianggap sebagai elemen kuat yang menjadi karakter bangsa tersebut. Keanekaragaman sumber daya arkeologi dan berasal dari berbagai masa sudah merefleksikan keanekaragaman etnik (multi culture) masyarakat pada masa itu sehingga perlu dipahami oleh masyarakat saat ini. Menginformasikan nilainilai ini kepada masyarakat luas 
dengan menjadikannya sebagai daya tarik wisata menjadi kunci penting bagaimana mutikulturalisme dapat diterima sebagai kesadaran nasional dan menjadi kekuatan besar untuk meningkatkan ketahanan budaya di masyarakat.

Sumber daya arkeologi sebagai tumpuan untuk ketahanan budaya dengan mewujudkan identitas budaya sangat tepat diterapkan di daerah Papua. Jati diri suatu bangsa dapat ditentukan oleh dua hal yaitu (1) warisan budaya yang berupa hasilhasil penciptaan di masa laludan (2) hasil-hasil daya cipta di masa kini yang didorong, dipacu, ataupun dimungkinkan oleh tantangan dan kondisi aktual dari jaman sekarang. Suatu bangsa terdiri dari satuansatuan etnik (suku) yang ditandai oleh kebudayaannya sebagai tanda jati diri maupun sebagai tanda pembeda dengan bangsa atau etnik lain. Seluruh hasil budaya suatu etnik atau suku bangsa adalah sosok dari jati diri pemiliknya yang bersifat dinamis (Sedyawati, 2006:379-383).

Sumber daya budaya termasuk di dalamnya sumber daya arkeologi sebagai potensi yang dikembangkan untuk meningkatkan ketahanan budaya melalui pengembangan pariwisata merupakan pilihan strategi untuk meminimalisasi dampak globalisasi. Nilai dan makna budaya pada setiap tinggalan arkeologi di Indonesia dapat menjadi counter culture dominasi budaya massa yang dikuasai oleh negara-negara maju dan berpengaruh besar terhadap pola pikir dan "budaya" masyarakat negaranegara berkembang.

Daya tarik unsur-unsur budaya dan kearifan lokal sebagai dasar pengembangan budaya dalam era global ini dapat lebih rinci berdasarkan alasan-alasan dari perspektif strategi kebudayaan, meningkatnya pengaruh globalisasi telah mereduksi nilainilai budaya nasional. Budaya lokal memiliki potensi dan peran sebagai budaya tandingan (counter culture) bagi dominasi budaya global yang dimitoskan sebagai sesuatu tidak bisa dielakkan (Fakih, 2001:5). Memunculkan nilai dan makna yang dimiliki sumber daya arkeologi pada konteks kekinian melalui pariwisata, sebagai salah satu sumber sikap kritis terhadap globalisasi. Pada masa globalisasi masyarakat dengan mudah meniru dan menerapkan gaya hidup dari berbagai belahan dunia, sehingga menjadi homegen.

Memunculkan nilai dan makna budaya warisan budaya masa lalu masyarakat Papua dengan menjadikannya sebagai daya tarik wisata merupakan salah satu gerakan revitaslisasi budaya lokal untuk menahan laju degradasi identitas budaya masyarakat. Menengok kembali produk budaya masyarakat masa lalu dengan memberikan nilai dan makna sesuai dengan konteks masyarakat saat ini dapat dilakukan dengan menjadikannya sebagai sumber daya.

Dalam memaknai sumber daya arkeologi sebagai daya tarik wisata di Papua harus secara kontektual dan bukan hanya untuk kepentingan ekonomi, karenabudaya adalah sesuatu yang dinamis dan kontekstual dengan jamannya. Tinggalan arkeologi sebagai wujud kebudayaan untuk membentuk ketahanan budaya dapat dilakukan melalui pariwisata karena dapat meningkatkan rasa cinta tanah air (patriotism) melalui pemahaman, meningkatkan pelestarian, dan memberikan apresiasi kepada masyarakat yang berusaha 
mengembangkan kebudayaan asli atau lokal mereka dengan menjadikan sebagai daya tarik wisata. Ketahanan budaya masyarakat Papua sangat penting perannya dalam proses perubahan sosial budaya secara nasional. Secara internal budaya lokal dapat sebagai alat atau pembeda dan pemersatu bangsa karena pada hakekatnya Indonesia merupakan negara yang sangat majemuk (multikultur).

Dampak sosial budaya dari industri pariwisata sangat sulit diukur secara kuantitatif sehingga para pelaku usaha pariwisata terutama yang menjadikan warisan budaya sebagai sumber daya harus memprioritaskan dan melestarikan keunikan. Mengoptimalisasi peran masyarakat lokal sangat penting karena pada masyarakat melekat keunikan dankeragaman budaya dalam menciptakan identitas dan jati diri, sebagai bagian daripengembangan pariwisata secara inklusif untuk meningkatkan ketahan budaya. Meningkatkan ketahanan budaya melalui pemberdayaan sumber daya arkeologi di Papua sebagai daya tarik wisata merupakan embrio terbentuknya sebuah citra positif dan identitas masyarakat lokal. Salah satu motivasi wisatawan berkunjung ke suatu destinasi ditentukan oleh citra dan identitas dari suatu daerah tujuan wisata.

Warisan budaya tangible dalam bentuk sumber daya arkeologi yang dimiliki oleh masyarakat Papua merupakan sebuah simbol identitas budaya daerah yang memperkuat budaya nasional, sebagai sebuah sumber pencarian jati diri. Dimana, kita ketahui sebagai sebuah bangsa yang besar Indonesia memiliki kesadaran tentang masa lampau dan memiliki segala perspektif mengenai bagaimana masa lampau serta segala peristiwa yang terjadi pada masa lampau. Kesadaran masa lampau masyarakat Papua dan daerah-daerah lainnya akan menumbuhkan kesadaran nasional. Di beberapa negara warisan masa lampau punya arti penting untuk membangun ideologidanjatidiri. Belajar dari keberhasilan ini sudah seharusnya sumber daya arkeologi yang ada pada setiap daerah dianggap penting untuk dipertahankan sebagai sebuah tinggalan masa lalu yang memiliki nilai penting untuk membangun ideologi bagi pemerintahan yang berkuasa dengan melakukan pengelolaan yang tepat.

Jika pengaruh budaya dari luar menyebabkan jati diri budaya lama berubah oleh pengambilalihan unsur-unsur budaya lain secara besarbesaran (akulturasi) dan membentuk sosok budaya baru, tetapi masih membawa atau menunjukan warisan budaya lama dapat berfungsi sebagai jati diri atau identitas yang berlanjut. Sementara itu, jika rangsangan atau gagasan dari luar dapat mencabut akar budaya lama dan di isi dengan budaya baru yang tidak terkait dengan aspek tradisi atau warisan budaya yang lama, menyebabkan warisan budaya tidak lagi mempunyai kekuatan untuk membentuk jati diri (Sedyawati, 2006:379-383).

Dengan demikian, mempertahankan nilai dan makna yang terkandung dalam setiap warisan budaya baik secara utuh maupun sudah mendapat pengaruh unsur budaya luar tetapi tetap menunjukan ciri khas budaya lokal maka sumber daya budaya ini dapat memperkuat atau penentu jati diri daerah ini. Warisan budaya yang ditemukan di Papua seperti pemilihan pemukiman 
masa lalu di gua-gua dan perbukitan, jejak-jejak Perang Pasifik, tinggalan masa Islam arsitektur, dan bahan baku yang berbeda-beda dan mencirikan beberapa daerah bahkan perpaduan berbagai negara di dunia.

Keanekaragaman etnis yang diwujudkan dalam berbagai bentuk kebudayaan materi menunjukan nilai dan makna simbolis. Hal inimenunjukan bahwadaerah Papua sejak masa lalu sudah mempunyai karakter multiculture dan mereka dapat hidup berdampingan. Warisan budaya yang di daerah ini menunjukan secara tidak langsung karakter masyarakat daerah ini sejak dahulu sangat menghargai kemajemukan. Nilai ini tentunya masih sangat relevan untuk diterapkan dengan kondisi budaya masyarakat Papua yang sangat beragam sehingga dapat meminimalisasi disintegrasi.

\section{Daerah Papua mempunyai} sumber daya arkeologi dari masa prasejarah sampai masa perang Pasifik yang bersumber dari budaya lokal masyarakat dan terus mengalami dinamika berjalan seiring secara harmonis membentuk identitas masyarakat sebagai bentuk identitas lokal. Nilai budaya yang terkandung pada setiap sumber daya ini menginspirasi kehidupan dan interaksi sesama masyarakat Papua yang berada di dalamnya. Munculnya nilai dan makna budaya sumber daya arkeologi dalam konteks kekinian terutama untuk kepentingan ideologik untuk meningkatkan ketahanan budaya bukan berarti kembali sepenuhnya kepada masa lampau dan menolak realitas kekinian yang terus berubah.

Menurut Gidden (2010: 34) kebanyakan apa yang dianggap tradisi di masa kini, telah melewati batas waktu dengan mengalami penyesuaian dengan perkembangan- perkembangan baru. Artinya, bahwa sumber daya arkeologi sebagai jejak budaya masa lalu dapat direvitalisasi untuk memperkuat ketahanan budaya dan identitas suatu daerah, komunitas atau kelompok sosial, komunitas atau kelompok sosial, sekalipun budaya itu tidak lagi asli sebagaimana budaya itu hidup dan dimaknai di masa lalu.

Kunjungan wisatawan ke suatu destinasi tentunya ada interaksi sosial dengan masyarakat lokal, dengan latar belakang budaya yang berbeda. Swarbrooke (1998: 71) menjelaskan dengan lebih jelas, bahwa kunjungan wisatawan ke suatu daerah tujuan wisata menyebabkan terjadinya proses adaptasi baik adaptasi terhadap lingkungan fisik maupun kultural masyarakat setempat.

Hal ini juga mengakibatkan jejak-jejak budaya masyarakat masa lampau yang ditemukan pada masing-masing daerah mempunyai ciri khas dan keuinikan masingmasing. Potensi ini menjadi daya tarik bagi wisatawan baik lokal maupun mancanegara. Perubahan yang terjadi dalam masyarakat dan budaya akan dapat mengalami transformasi secara drastis. Adaptasi merupakan suatu proses yang menghubungkan sistem budaya dengan lingkungan (Kaplan, 2000: 84, 112).

Perubahan yang terjadi terhadaplingkungan, baik yang bersifat cepat maupun lambat, akan direspon oleh manusia dengan cara beradaptasi terhadap perubahan itu. Perubahan sosial dimaksudkan adanya proses yang dialami dalam kehidupan sosial yaitu perubahan yang mengenai sistem dan struktur sosial. Perubahan sosial dapat mengenai nilai-nilai sosial, pola - pola perilaku organisasi, susunan lembaga kemasyarakatan, lapisan dalam masyarakat, kekuasaan 
dan wewenang, interaksi sosial dan sebagainya.

\section{PENUTUP}

Indonesia tidak bisa terhindar dari dampak arus globalisasi dan modernisasi baik dampak positif di bidang ekonomi dan IPTEK, maupun dampak perubahan sosial budaya yang sudah menjangkau hampir seluruh lapisan di masyarakat. Untuk meminimalisasi pengaruh negatif ini potensi kekayaan budaya lokal yang sangat beragam menjadi modal dalam membentengi pribadi masyarakat. Tinggalan arkeologi merupakan salah satu wujud kebudayaan materi yang banyak ditemukan tersebar di seluruh Nusantara termasuk di daerah Papua yang mempunyai keunikan dan ciri khas tersendiri sesuai dengan budaya lokal. Tinggalan arkeologi ini dapat diberdayakan untuk kepentingan ekonomi sebagai daya tarik wisata dan kepentingan ideologik untuk memperkuat identitas dan jatidiri masyarakat. Sumber daya arkeologi di Papua mempunyai potensi besar dijadikan sebagai daya tarik wisata karena mempunyai keunikan dan ciri khas tersendiri yang menunjukan nilai dan etnik masyarakat pendukungnya. Jejak budaya masyarakat Papua sangat beraneka ragam baik dari jenis maupun masa peradaban (dari prasejarah sampai pada masa Perang Pasifik) sehingga dapat menjadi kebanggaan masyarakat dan penentu jatidiri. Untuk mewujudkan hal ini, maka nilai dan makna budaya sesuai dengan konteks masyarakat sekarang harus dipahami oleh generasi sekarang.

Perkembangan industripariwisata yang menjadi sektor prioritas dalam pembangunan nasional tentunya juga meningkatkan interaksi dan mobilitas masyarakat Papua terhadap dunia. Persentuhan dan percampuran budaya, antar etnik dan antarbangsa tidak dapat dihindari karena wisatawan datang ke suatu destinasi tentunya dengan budayayang notabena berbeda dengan budaya lokal sehingga dapat meningkatkan degradasi ketahanan budaya di masyarakat.

Untuk itu, memberdayakan sumber daya arkeologi sebagai daya tarik wisata di Papua merupakan strategi untuk pelestarian dengan memunculkan nilai dan makna budaya warisan budaya dengan konteks kekinian. Melalui Pariwisata akan memunculkan rasa solidaritas, cinta tanah air, persatuan dan kesatuan, gotong royong serta citra positif terhadap budaya dan daerahnya. Pemahaman dan informasi nilai-nilai budaya yang disampaikan kepada masyarakat luas melalui industri pariwisata dapat meningkatkan ketahan budaya ketahanan budaya masyarakat Papua di era globalisasi sekaligus memberikan manfaat secara ekonomi. Strategi ini juga merupakan salah satu gerakan revitaslisasi budaya masyarakat Papua untuk menahan laju degradasi identitas budaya masyarakat sehingga secara internal ketahanan budaya meningkat. 


\section{DAFTAR PUSTAKA}

Anonim. 2009. Undang-Undang Republik Indonesia tentang Pariwisata. Jakarta: Kemenbudpar.

Anonim. 2007. Kamus Besar Bahasa Indonesia. Jakarta: Badan Bahasa.

Ariani, Made. 2011. "Pergulatan Otentisitas dan Komodifikasi dalam Pariwisata Budaya (Studi Kasus Desa Tenganan Pegringsingan, Karangasem, Bali)". Analisis Pariwisata. Vol. 11 No. 1. Denpasar: Fakultas Pariwisata Universitas Udayana.

Bonafice, P. 1995. Managing Quality Cultural Tourism. London: Roetledge.

Cleere, Henry. 1989. "Introduction:The Rationale of Archaeological Heritage Management" dalam Henry F. Cleere (ed), Archaeological Heritage Management in the Modern World (pp. 1-19). London: Unwin Hyman.

Fakih, Mansour. 2001. Analisis Gender dan Transformasi Sosial. Yogyakarta: PustakaPelajar.

Feilden, Bernard M dan Jukka Jokilehto. 1993. Management Guidelines for World CulturalHeritage Sites. Italy: ICCROM.

Giddens, Anthony. 2010. Teori Strukturasi. Dasar Dasar Pembentukan Struktur Sosial Masyarakat. Yogyakarta: Pustaka Pelajar.

Kaplan, Robert S. dan David P. Norton. 2000. Balanced Scorecard: Menerapkan Strategi Menjadi Aksi. Jakarta: Erlangga.

Macleod, Donald G. 1977. "Peddle or Perish:Archaeological Marketing from Concept to Product Delivery" dalam Michael B. Schiffer dan George J. Gumerman (ed.). Conservation Archaeology A Guide for Cultural Resources Management Studies (pp. 63-72). New York: Academic Press.

Mill, Robert Christie. 2000. Tourism The International Business Edisi Bahasa Indonesia. Jakarta: PT Raja Grafindo Persada.

Pendit, Nyoman S. 2002. Ilmu Pariwisata. Jakarta: Pradnya Paramita.

Sedyawati. Edi. 2006. "Warisan Budaya Intangible yang Tersisa dalam yang Tangible". Budaya Indonesia: Kajian Arkeologi, Seni, dan Sejarah. Jakarta: PT Raja Grafindo Persada.

Swarbrooke, John. 1999. Sustainable Tourism Management. CABI Publishing.

Tien, Chieh-Ching. 2003. The Role of Museum Cluster in the Cultural Tourism Industry.

Tanudirjo, Daud Aris. 2003. "Warisan Budaya untuk Semua: Arah Kebijakan Pengelolaan Warisan Budaya Indonesia di Masa Mendatang". Makalah disampaikan pada Kongres Kebudayaan Bukittinggi.

Tim Peneliti. 1999. Laporan Penelitian Arkeologi Islam di Kecamatan Fakfak, Kabupaten Fakfak, Irian Jaya. Balai Arkeologi Papua. 
Onim, J.F. 2006. Islam dan Kristen di Tanah Papua. Bandung: Jurnal Info Media. Riyanto, S. 2006. "Pengelolaan Informasi di Taman Wisata Candi Prambanan: Kajian tentang Keterkaitannya dengan Peningkatan Apresiasi Masyarakat terhadap Benda Cagar Budaya". Tesis Program Pasca Sarjana UGM. Yogyakarta.

Yoeti, Oka A. 2002. Perencanaan Strategis Pemasaran Daerah Tujuan Wisata. Jakarta: Pradnya Paramita.

\section{INTERNET}

http://sains.kompas.com/read/2014/05/21/2123550/Kampung.Prasejarah. Ditemukan.di.Papua diakses pada 12 Juni 2016.

http://sains.kompas.com/read/2010/04/07/06421085/Papua.Miliki.Keragaman. Arkeologi diakses pada tanggal 12 Juni 2016.

http://prokimal-online.blogspot.com/2013/01/situs-situs-arkeologi-militer-perang. html diakses pada tanggal 12 Juni 2016.

http://news.metrotvnews.com/read/2015/02/04/353639/artefak-dan-makamsaudagar-arab-ditemukan-di-raja-ampat diakses pada 19 Juni 2016. 